\title{
RANCANG BANGUN TACHOMETER DIGITAL BERBASIS ARDUINO DILENGKAPI CHARGING DAN MODE PENYIMPAN DATA
}

\author{
Imam Tri Harsoyo ${ }^{1)}$, Andi Kurniawan Nugroho ${ }^{2)}$, dan Nuriman ${ }^{3)}$ \\ 1,3) Jurusan Teknik Elektro Medik, Akademi Teknik Elektro Medik Semarang \\ Jln. Kol. Warsito Soegiarto Km 2,5 Semarang. \\ 2) Jurusan Teknik Elektro, Universitas Semarang \\ Jln. Soekarno Hatta, Tlogosari Kulon, Kota Semarang \\ e-mail: imamtriharsoyo@atemsemarang.ac.id ${ }^{1)}$, andikn@usm.ac.id ${ }^{2}$, $\underline{\text { mantakupaz@gmail.com }}^{3)}$
}

\begin{abstract}
A good and feasible centrifuge is needed in the world of health, therefore a digital tachometer is needed to calibrate a centrifuge. Digital tachometer is a measuring instrument used to measure the rotation speed of a motor. This tachometer will be tested to function by being compared to using Digital Laser Photo Tachometer. This tachometer will display the number of rotations per minute of a motor according to the speed setting on the centrifuge using the output of this E18-D80NK sensor which will later be processed by the Arduino Nano. As for this feature charger and data storage mode, so that user can save the data of measurement results on SD Card, and beside that user can also be a way of charging when after usage or before usage. At testing the tool used point settings 1000, 2000, 3000, 4000, 5000, and 12000 RPM. Based on the measurement results of centrifuge using tachometer module and comparison tachometer have average percentage of error varying at each setting point. The smallest error $0.8 \%$ at the setting Point 3000 RPM, while the largest error $4.9 \%$ at the setting point 1000 RPM. The Tacometer error value on this Centrifuge measurement is still within the tolerance limit of $\pm 10 \%$.
\end{abstract}

Keywords: Arduino Nano, E18-D80NK Sensor, LCD, RPM, Tachometer.

\begin{abstract}
ABSTRAK
Centrifuge yang baik dan laik pakai sangat dibutuhkan dalam dunia kesehatan, oleh karena itu dibutuhkan tachometer digital untuk mengkalibrasi centrifuge. Tachometer digital merupakan alat ukur yang digunakan untuk mengukur kecepatan perputaran suatu motor. Tachometer ini akan diuji fungsi dengan dibandingankan menggunakan Digital Laser Photo Tachometer. Tachometer ini akan menampilkan jumlah rotasi per menit suatu motor sesuai dengan setting kecepatan pada centrifuge menggunakan output dari sensor E18-D80NK ini yang nantinya akan diproses oleh arduino nano. Adapun ini memiliki fitur charger dan mode penyimpanan data, sehingga user dapat menyimpan data hasil pengukuran pada SD Card, dan disamping itu user juga dapat melaukan pengisian daya apabila setelah pemakaian maupun sebelum pemakaian. Pada pengujian alat digunakan titik setting 1000, 2000, 3000, 4000, 5000, dan 12000 RPM. Berdasarkan hasil pengukuran dari centrifuge yang menggunakan tachometer modul dan tachometer pembanding memiliki rata -rata presentase error yang berbedabeda pada setiap titik setting. Error terkecil 0,8\% pada titik setting 3000 RPM, sedangkan error terbesar 4,9\% pada titik setting 1000 RPM. Nilai error Tacometer pada pengukuran Centrifuge ini masih di dalam batas toleransi yaitu $\pm 10 \%$.
\end{abstract}

Kata Kunci: Arduino Nano, Sensor E18-D80NK, LCD, RPM, Tachometer.

\section{Pendahuluan}

A lat kesehatan merupakan suatu penunjang medis juga merupakan salah satu faktor yang memegang peranan penting dalam menyelenggarakan pelayanan kesehatan kepada masyarakat. Menurut Permenkes Nomor 54 Tahun 2015 pasal 4 menyatakan bahwa setiap alat kesehatan yang digunakan di fasilitas kesehatan lainya harus dilakukan uji dan/ atau kalibrasi secara berkala oleh Balai Pengujian Fasilitas Kesehatan atau Institusi Pengujian Fasilitas Kesehatan [4].

Salah satu alat yang wajib dilakukan kalibrasi adalah Centrifuge. Centrifuge merupakan alat yang memiliki peranan yang penting di laboratorium. Alat centrifuge ini diperlukan dalam tahap separasi yaitu tahap pemisahan antara fase cairan dan padatan yang memanfaatkan gaya sentrifugal dengan kecepatan rotasi dan dalam jangka waktu tertentu [5]. Oleh karena itu diperlukan
Centrifuge yang baik dan laik pakai untuk mendapatkan hasil yang sesuai dengan cara dikalibrasi menggunakan Tachometer digital.

Umumnya Tachometer digital yang digunakan untuk melakukan kalibrasi Centrifuge itu memakai Tachometer digital yang menggunakan laser, karena penggunaan laser memiliki keunggulan jaungkauan jarak dan tingkat keakurasian yang tinggi.

Penelitian tentang tachometer non-contact berbasis arduino telah dilakukan untuk mengukur kecepatan suatu motor yang ada pada Centrifuge. Alat ini menampilkan jumlah rotasi permenit suatu motor sesuai dengan setting kecepatanya. Tachometer menggunakan laser, microcontroller ATMEGA 328 dan display untuk tampilan kecepatan [7]. Penelitian selanjutnya juga pernah dilakukan dengan merancang tachometer berbasis mikrokontroler dan dilengkapi dengan mode pengukuran RPM dan jarak. Tachometer dirancang 
menggunakan phototransistor, mikrokontroler ATMEGA 8 dan LCD karakter [1]. Penelitian selanjutnya tentang alat kalibrasi centrifuge non-contact berbasis microcontroller ATMEGA 8, phototransistor. Tachometer juga dilengkapi dengan mode penyimpanan untuk mempermudah user dalam melakukan kalibrasi pada centrifuge dan memudahkan user untuk mengolah data [8].

Berdasarkan dari penelitian sebelumnya penulis tertarik untuk membuat Tachometer Digital Berbasis Arduino Nano dengan penggunaan sensor E18-D80NK yang lebih efisien harganya jika dibandingkan dengan penggunaan modul sensor laser sebagai pendeteksi gerak rotasi pada centrifuge. Selain itu, penulis juga memberikan fitur charging untuk alat tachometer ini karena kebanyakan alat tachometer tidak bisa dilakukan charging. OLED display juga digunakan pada penelitian ini sebagai tampian kecepatan putaran dan penyimpanan data untuk mempermudah user. Adapun tujuan dari penelitian ini adalah membuat rangkaian tachometer digital berbasis arduino nano yang dilengkapi charging dan mode penyimpan data serta melakukan uji fungsi tachometer digital tersebut.

Alat Tachometer itu sendiri merupakan alat pengujian yang dirancang untuk mengukur kecepatan rotasi dari sebuah objek, seperti alat pengukur dalam sebuah mobil yang mengukur putaran per menit (RPM) dari poros engkol mesin [9]. Alat Tachometer menunjukan RPM mesin dengan mengukur rotasi poros mesin perangkat yang menyerupai generator listrik yang bervariasi sesuai dengan kecepatan putaran mesin. Arus listrik yang dihasilkan ini kemudian di konversikan dalam RPM [10].

Salah satu contoh penggunaan Tachometer adalah pada pengukuran kecepatan rotasi pada alat laboratorium seperti Centrifuge, jenis Tachometer yang digunakan adalah Tachometer laser seperti pada gambar 1 .

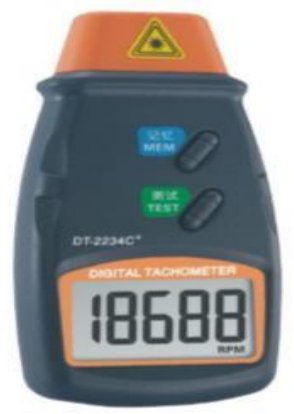

Gambar 1. Tachometer laser (introduction for dt-2234C+ Digital Tachometer. 2015)

Tachometer ini memungkinan untuk pengukuran dari jarak jauh di mana alat Tachometer Laser ini bekerja dengan sensor cahaya yang sangat sensitip dengan elemen berputar. Unsur berputar akan memiliki satu tempat reflektif dan rpm meter ini mengukur tingkat dimana berkas cahaya dipantulkan kembali [2].

Penggunaan tachometer yang baik dan benar adalah sebagai berikut:

1. Gunakan tanda reflektif pada objek yang akan diukur

2. Tekan tombol pengukur dan sejajarkan berkas cahaya tampak dengan target

3. Verifikasi indikator monitor muncul di LCD jika target sejajar dengan cahaya sekitar 1 atau 2 detik

4. Lepaskan tombol pengukuran ketika pembacaan RPM stabil di LCD [11].

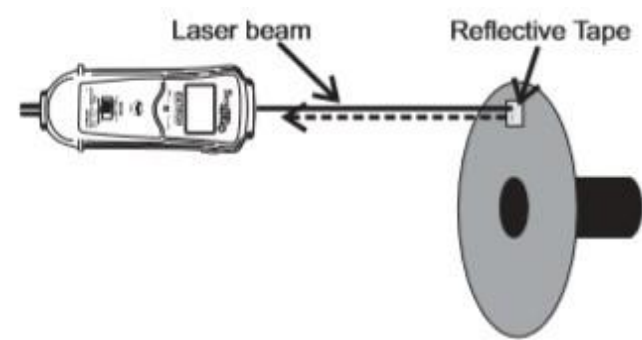

Gambar 2. Cara kerja Tachometer (user's guide extech instrument company. 2011)

Pada penelitian ini menggunakan Infrared Proximity Sensor. Sensor Infrared Proximity merupakan sensor yang dapat merasakan keberadaan suatu benda tanpa menyentuh benda tersebut yaitu dengan menggunakan infrared. Sensor ini hanya dapat mendeteksi apakah ada benda yang menghalangi atau tidak ada, sensor tidak dapat mengetahui jarak ke benda tersebut. Transmiter dan receiver yang ada di dalam sensor tersebut menghadap kearah yang sama, dimana receiver akan menerima pantulan sinar infrared dari transmitter [3].

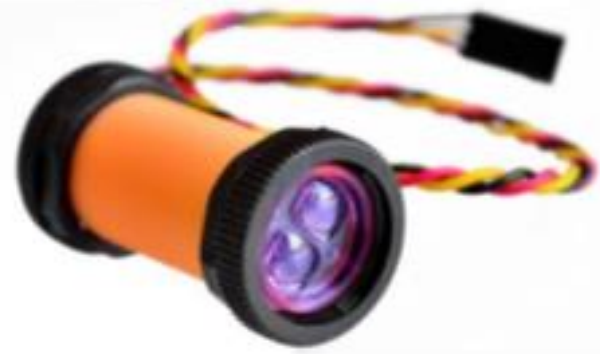

Gambar 3. Infrared Proximity Sensor (E18-D80NK)(A. Gunawan. 2016)

Spesifikasi Infrared Proximity Sensor sebagai berikut:

- Jarak deteksi $3 \mathrm{~cm}-80 \mathrm{~cm}$.

- Sudut Deteksi: 150 atau kurang

- Tegangan $5 \mathrm{~V}$ DC.

- Waktu Respon < 2 ms

- Arus beban maks $100 \mathrm{~mA}$.

- Diameter: $18 \mathrm{~mm}$, panjang: $45 \mathrm{~mm}$.

- Bekerja pada temperature: $-25-70{ }^{\circ} \mathrm{C}$

- Merah +5 V, Kuning Sinyal, Hitam GND 
Pada penelitian ini menggunakan Charging Module TP4056. Modul charging ini cocok digunakan untuk 1 buah baterai dengan keluaran $3.7 \mathrm{~V}$, dan $1 \mathrm{Ah}$ (Ampere per Hour) atau lebih tinggi, seperti baterai tipe 16550 yang tidak mempunyai sirkuit proteksi didalamnya. Berdasarkan charging IC TP4056 dan, DW01 battery protection, modul ini dapat menyediakan arus $1 \mathrm{Am}$ pere, dan juga proteksi tegangan baterai, yang jika tegangan baterai turun dibawah $2.4 \mathrm{~V}$, IC battery protection akan langsung memindahkan beban dari baterai, agar mencegah baterai mempunyai tegangan yang terlalu rendah, dan juga ada proteksi over voltage baterai [4].

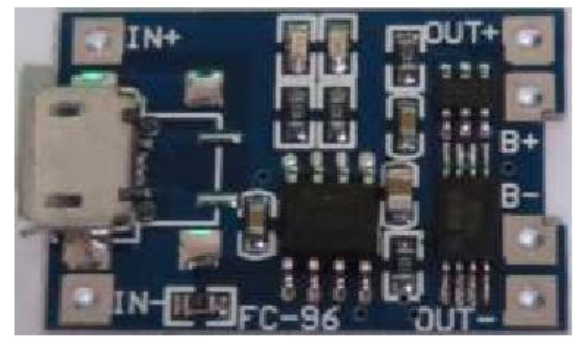

Gambar 4. Module Charging TP4056 (I. Hamddin. 2018)

\section{METOdE PENELITIAN}

Penelitian ini dilakukan di Laboratorium Akademi Teknik Elektro Medik Semarang. Adapun prinsip kerja keseluruhan dari alat tachometer dapat dilihat pada blok diagram rangkaian tachometer. Blok diagram rangkaian tachometer dapat ditunjukkan pada gambar 5.

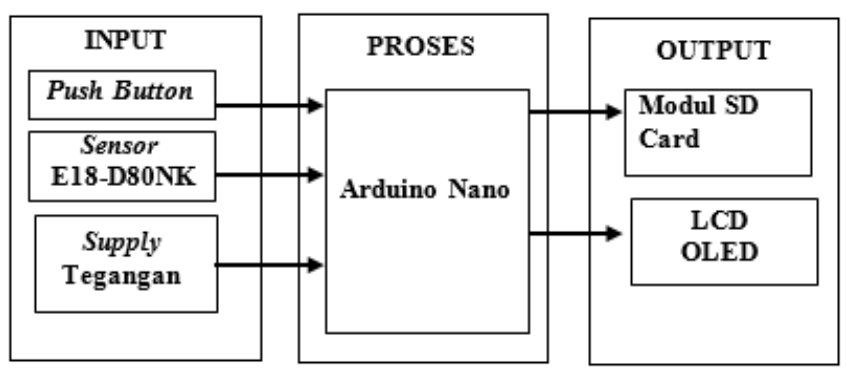

Gambar 5. Blok Diagram Tachometer

Supply Tegangan akan memberikan tegangan ke Arduino Nano. Ketika arduino nano mendapatkan supply tegangan dari rangkaian supply tegangan maka arduino nano akan memberikan tegangan $5 \mathrm{~V}$ ke semua rangkaian yang terhubung pada arduino. Rangkaian arduino nano sendiri berfungsi sebagai pengontrol seluruh rangkaian termasuk mengolah input-an untuk ditampilkan di LCD sebagai output. Sensor akan mulai melakukan perhitungan RPM disaat Push Button di tekan. Disaat sensor aktif, sensor akan memancarkan sinar infrared (transmitter) pada bidang reflective yang kemudian di terima oleh fototransistor (receiver).
Rangkaian display disini berfungsi sebagai output. Sedangkan Push Button sendiri berfungsi untuk menjalankan pengukuran. Adapun wiring diagram keseluruhan alat dapat dilihat pada gambar 6 .

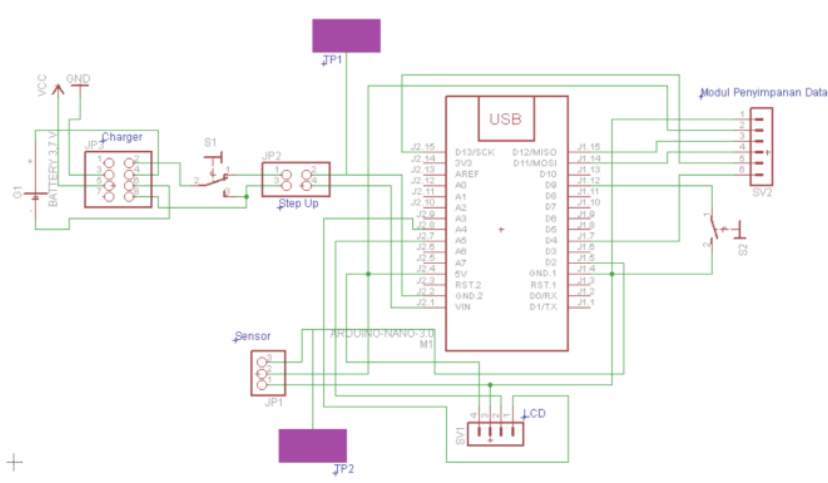

Gambar 6. Wiring Diagram Alat.

Dalam wiring diagram diatas terdiri dari beberapa rangkaian diantaranya: Rangkaian supply tegangan, Rangkaian LCD, Rangkaian modul Penyimpan Data, Rangkaian Arduino Nano, dan Rangkaian Sensor.

\section{Rangkaian Supply Tegangan}

Alat tachometer yang dibuat menggunakan supply tegangan baterai 3,4 V yang dihubungkan ke modul power bank untuk dapat di charger sewaktu-waktu yang langsung tersambung dengan Switching ON/OFF kemudian masuk ke rangkaian modul step-up untuk menaikan tegangan ke $5 \mathrm{~V}$ DC ke arduino nano.

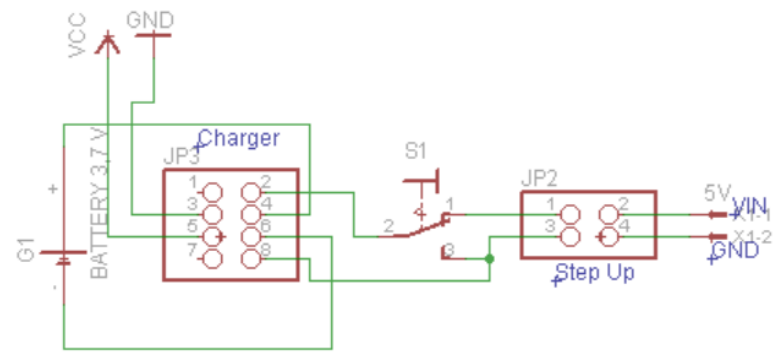

Gambar 7. Rangkaian Supply Tegangan.

\section{Rangkaian Sensor}

Penulis menggunakan sensor E18-D80NK yang dimana untuk pembacaanya ketika sinar infrared mengenai bidang reflektif yang tidak berwarna hitam maka indikator led akan menyala, sedangkan ketika infrared mengenai bidang reflektif yang berwana hitam maka indikator led tidak menyala.

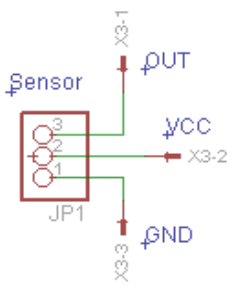

Gambar 8. Rangkaian Sensor 


\section{Rangkaian Arduino Nano, Push Button, dan LCD}

Penulis menggunakan Arduino Nano sebegai pengontrol rangkaian, adapun penggunaan Push Button sebagai tombol untuk mengaktifkan pengukuran RPM, sedangkan untuk menampilkan pengukuran penulis menggunakan LCD OLED.

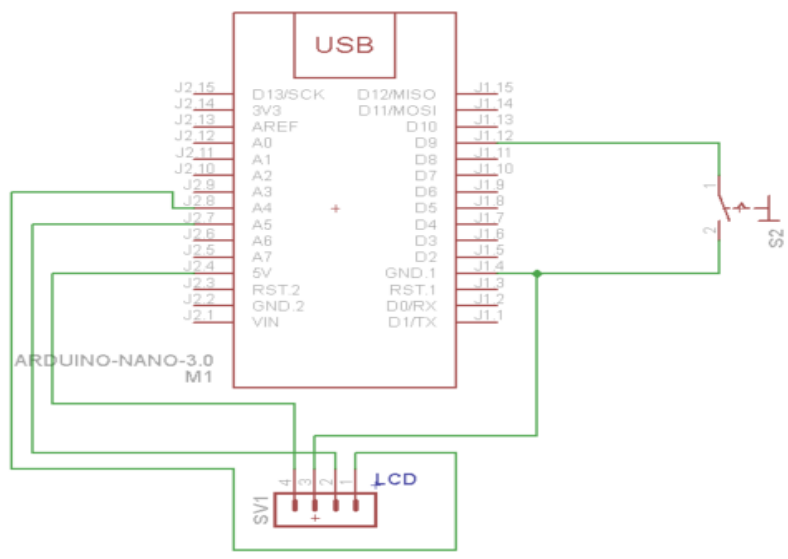

Gambar 9. Rangkaian Arduino Nano, Push Button, dan LCD

\section{Rangkaian Penyimpanan Data}

Prinsip kerja dari modul penyimpanan data dari alat yang dibuat penulis adalah ketika tombol pengukuran dilepas maka data otomatis tersimpan, adapun gambar rangkaian penyimpanan data seperti gambar dibawah ini.

Modul Penyimpanan Data

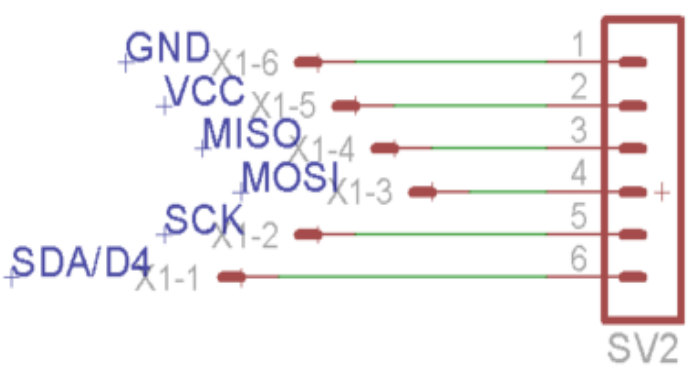

Gambar 10. Rangkaian Penyimpanan Data

\section{Perangkat Lunak}

Perangkat lunak merupakan suatu perangkat yang digunakan untuk memproses suatu data atau suatu aplikasi yang digunakan untuk memprogram suatu perangkat keras. Perangkat lunak yang digunakan penulis adalah Bascom AVR untuk menghubungkan program dengan Arduino Nano. Program yang dibuat akan menjadi suatu instruksi yang akan terus dijalankan ketika Arduino nano diaktifkan.

\section{Flowchart Software}

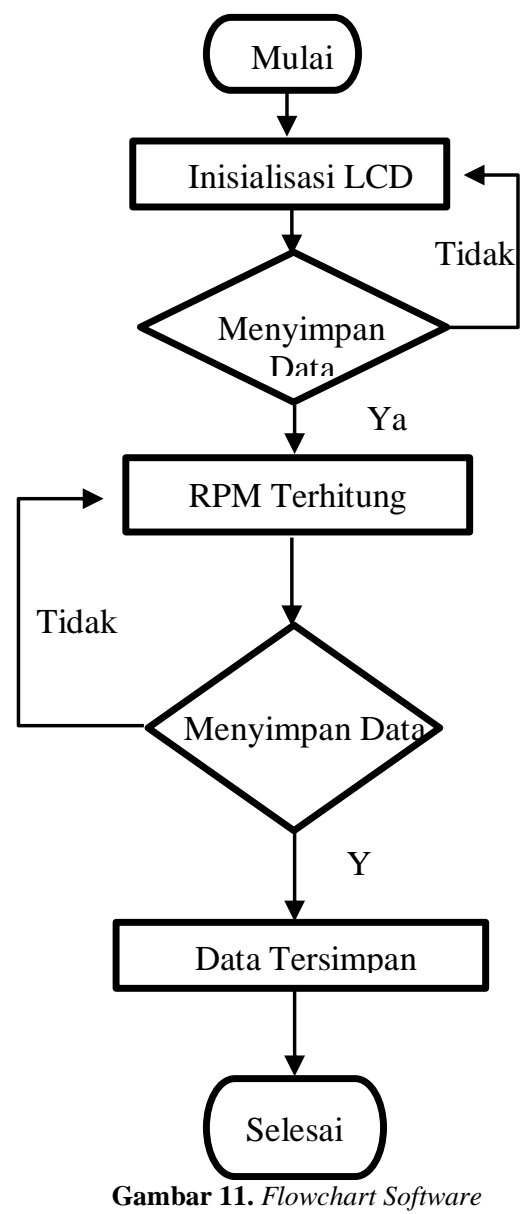

Langkah pertama mengkondisikan semua rangkaian yang akan diprogram, kemudian proses inisialisasi untuk mengkondisikan semua rangkaian terhubung dengan port yang direncanakan pada Arduino Nano. Setelah itu tekan push button maka alat akan menghitung RPM. Apabila ingin menyimpan data maka tekan push button sekali lagi maka data akan tersimpan, proses selesai.

\section{Desain Alat}
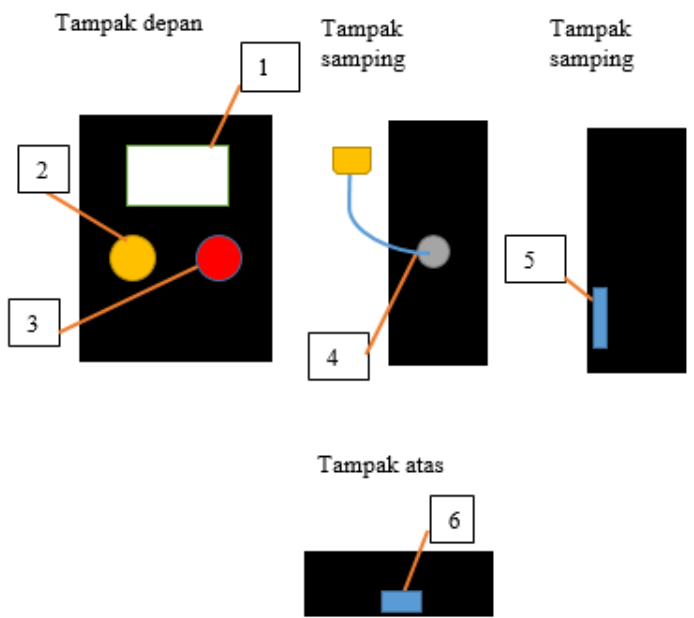

Gambar 12. Desain Alat 
Keterangan:

Tampak depan

1. LCD

2. Push Button

3. Switch $\mathrm{ON} / \mathrm{OFF}$

Tampak samping kiri

4. Sensor

Tampak samping kanan

5. Penyimpanan data

Tampak atas

6. Tempat pengisian daya

\section{HASIL DAN PEMBAHASAN}

\section{Analisa Hasil Pengukuran TP1}

Tegangan yang diperlukam oleh alat adalah sebesar 5 V DC. Pengukuran tegangan dilakukan menggunakan alat ukur Heles multitester. Pengukuran dilakukan sebanyak 5 kali dengan selisih tiap pengukuran selama 1 menit. Hasil pengukuranya dapat dilihat pada table I:

Tabel I

Pengukuran Supply Tegangan

\begin{tabular}{|c|c|c|c|c|c|c|}
\hline \multirow{2}{*}{ No } & Titik & \multicolumn{5}{|c|}{ Hasil Pengukuran (5 V DC) } \\
\cline { 3 - 7 } & Pengukuran & 1 & 2 & 3 & 4 & 5 \\
\hline 1 & TP1 & 5,17 & 5,17 & 5,17 & 5,17 & 5,17 \\
\hline
\end{tabular}

Jadi hasil pengukuran pada tabel 4.1 keluaran dari Supply Tegangan yang dibuat sesuai dengan perencanaan yang dimana keluaranya dari tegangan awal 3,4 V DC. Pada hasil titik pengukuran yaitu pada tegangan $5 \mathrm{~V}$ DC dan pengkuran dilakukan sebanyak 5 kali dengan selisih waktu 1 menit didapatkan hasil TP1 yaitu 5,17 V DC.

\section{Analisa Hasil Pengukuran TP2}

Pengujian alat dilakukan langsung dengan Centrifuge. Pengujian alat dilakukan dengan cara membandingkan hasil antara pengkalibrasian Centrifuge menggunakan Digital Laser Photo Tachometer dengan pengkalibrasian Centrifuge menggunakan Rancang Bangun Tachometer Digital Berbasis Arduino Nano. Perbandingan dilakukan secara bersamaan antara alat Rancang Bangun Tachometer Digital Berbasis Arduino Nano dengan Digital Laser Photo Tachometer. Perbandingan dilakukan sebanyak 6 kali pada skala alat ukur. Hasil perbandinganya dapat dilihat pada tabel II.
Tabel II

Perbandingan antara alat ukur pembanding dengan Rancang modul pada alat Centrifuge

\begin{tabular}{|c|c|c|c|c|c|c|c|c|}
\hline \multirow{2}{*}{ Alat } & \multirow{2}{*}{$\begin{array}{c}\text { Titik } \\
\text { Setting }\end{array}$} & \multicolumn{6}{|c|}{ Hasil pengukuran } & \multirow{2}{*}{$\begin{array}{l}\text { Rata- } \\
\text { Rata }\end{array}$} \\
\hline & & 1 & 2 & 3 & 4 & 5 & 6 & \\
\hline $\mathrm{P}$ & \multirow{2}{*}{1000} & 1027 & 1024 & 1024 & 1026 & 1024 & 1024 & 1024 \\
\hline $\mathrm{M}$ & & 944 & 1003 & 944 & 1003 & 944 & 1003 & 973 \\
\hline $\mathrm{P}$ & \multirow{2}{*}{2000} & 2006 & 2007 & 2004 & 2001 & 2003 & 2005 & 2004 \\
\hline M & & 2065 & 2006 & 2065 & 2006 & 2065 & 2006 & 2035 \\
\hline $\mathrm{P}$ & \multirow{2}{*}{3000} & 3003 & 3005 & 3001 & 3002 & 3003 & 3004 & 3003 \\
\hline M & & 3068 & 3009 & 3009 & 3068 & 2950 & 3068 & 3028 \\
\hline $\mathrm{P}$ & \multirow{2}{*}{4000} & 4010 & 4011 & 4011 & 4012 & 4010 & 4012 & 4011 \\
\hline M & & 4071 & 4071 & 4130 & 4071 & 4130 & 4071 & 4090 \\
\hline $\mathrm{P}$ & \multirow{2}{*}{5000} & 4864 & 4862 & 4864 & 4856 & 4856 & 4861 & 4860 \\
\hline M & & 4956 & 4897 & 4897 & 4838 & 4897 & 4957 & 4907 \\
\hline $\mathrm{P}$ & \multirow{2}{*}{12000} & 11916 & 11913 & 11915 & 11921 & 11921 & 11915 & 11910 \\
\hline M & & 12036 & 12095 & 12036 & 12095 & 12036 & 12095 & 12036 \\
\hline
\end{tabular}

Tabel III

Hasil Persentase kesalahan perbandingan antara perbanding dan modul

\begin{tabular}{|c|c|c|}
\hline No. & Titik Setting & $\begin{array}{c}\text { Hasil Presentase } \\
\text { Kesalahan RPM }\end{array}$ \\
\hline 1 & 1000 & $4,9 \%$ \\
\hline 2 & 2000 & $1,5 \%$ \\
\hline 3 & 3000 & $0,8 \%$ \\
\hline 4 & 4000 & $1,9 \%$ \\
\hline 5 & 5000 & $0,9 \%$ \\
\hline 6 & 12000 & $1,2 \%$ \\
\hline
\end{tabular}

Jadi hasil analisa data Tabel III hasil pengukuran TP2 didapat hasil presentase kesalahanya pada titik setting 1000 RPM sebesar 4,9\%, pada titik setting 2000 RPM sebesar 1,5\%, pada titik setting 3000 RPM sebesar 0,8\%, dan pada titik setting 5000 RPM sebesar $0,9 \%$. Dari hasil pengukuran pada Centrifuge 5000 RPM didapatkan error terbesar antara pembanding dengan modul pada titik setting 1000 RPM dan error terkecil pada titik setting 3000 RPM, sedangkan pada hasil pengukuran pada Centrifuge 12000 RPM didapatkan error $1,2 \%$.

\section{KESIMPULAN}

Setelah menyelesaikan pembuatan Tachometer Digital Berbasis Arduino Nano, mulai dari pengamatan dilapangan, studi pustaka, perencanaan, percobaan, pendataan dan analisa data, maka penulis mengambil kesimpulan sebagai berikut:

1. Untuk membuat Rancang Bangun Tachometer Digital Berbasis Arduino Nano dibutuhkan 
Sensor E18-D80NK, Arduino Nano sebagai pengontrol system kerja alat dan LCD Oled sebagai penampil hasil, dengan tambahan penyimpanan data dan fitur charger, kemudian board Arduino Nano akan dikonfigurasikan menggunakan aplikasi Arduino, setelah itu program dari aplikasi Arduino akan di input-kan ke Arduino Nano untuk mengontrol seluruh rangkaian yang terhubung pada board Arduino Nano.

2. Tachometer Digital Berbasis Arduino Nano dapat membaca perputaran rotasi motor dari centrifuge menggunakan sensor E18-D80NK. Berdasarkan hasil pengukuran dari centrifuge yang menggunakan tachometer modul dan tachometer pembanding memiliki rata -rata presentase error yang berbeda-beda pada setiap titik setting. Error terkecil 0,8\% pada titik setting 3000 RPM, sedangkan error terbesar 4,9\% pada titik setting 1000 RPM. Nilai error Tacometer pada pengukuran Centrifuge ini masih di dalam batas toleransi yaitu $\pm 10 \%$.

\section{DAFTAR Pustaka}

[1] Adillah, R. 2017. Tachometer Berbasis Mikrokontroler Dilengkapi dengan Mode Pengukuran RPM dan KM. Surabaya.

[2] Cheng, C. H., Schmitz, T. L., \& Scott Duncan, G. (2007). Rotating tool point frequency response prediction using RCSA. Machining Science and Technology, 11(3), 433-446.

[3] Gunawan, A. 2016. Algoritma Pendeteksian Obstacle dan Furniture Menggunakan Metode E Triangulasi dan Scanning Pada Robot Berkaki Enam yang Diterapkan pada Kontes Robot Pemadam Api Idonesia. Salatiga.

[4] Hamiddin, I. 2018. SAKLAR OTOMATIS SISTEM KONTROL TERPADU MENGGUNAKAN ARDUINO NANO. Yogyakarta.

[5] Ismail, R. 2015. Centrifuge: Alat Separasi Pada Sampel Fase Suspensi Dalam Kegiatan Praktikum Dan Penelitian. Bogor.

[6] Menteri Kesehatan Republik Indonsia. 2015. Peraturan Menteri Kesehatan Republik Indonesia Nomor 54 Tahun 2015 Tentang Pengujian dan Kalibrasi Alat Kesehatan. Jakarta.

[7] Nikmah, S, M. 2016. Tachometer Non Contact Berbasis Arduino. Surabaya.

[8] Pratama, A, R. 2017. Alat Kalibrasi Centrifuge Non Contact Berbasis Microcontroller Atmega 8. Yogyakarta.

[9] Rana, M. M., Sahabuddin, M., \& Mondol, S. 2016. Design and Implementation of a Digital Tachometer. memory, 2,3 .
[10] Restivo, M. T., de Almeida, F. G., Chouzal, M. D. F., Mendes, J. G., \& Lopes, A. M. 2011. Handbook of laboratory measurements and instrumentation. International Frequency Sensor Association.

[11] User's Guide Extech Instruments Company. 2011. Model RPM 10 Laser Photo/ Contact Tachometer with IR Thermometer. Boston. 